\title{
How to Do Language Policy with Dictionaries
}

\author{
Henning Bergenholtz, Department of Afrikaans and Dutch, University of \\ Stellenbosch, Stellenbosch, Republic of South Africa and Centre for \\ Lexicography, Aarhus School of Business, Aarhus, Denmark (hb@asb.dk) and \\ Rufus H. Gouws, Department of Afrikaans and Dutch, University of \\ Stellenbosch, Stellenbosch, Republic of South Africa (rhg@sun.ac.za)
}

\begin{abstract}
The lexicographical presentation of terms from the field of language planning often lacks clear and unambiguous distinction and proper explanation. Too often dictionaries even fail to include these terms in the lemma list, and some central terms have not been treated in any general or special purpose dictionary. This article utilises results from research in the field of language policy to make suggestions for the lexicographical presentation and treatment of a number of relevant terms. The emphasis on a distinction between language policy as applied to the intralingual and the interlingual level and the motivation for the introduction of the notion of a communication policy should help lexicographers to give a more comprehensive account of terms from this field and it will also benefit scholars in the field of language policy. A second aspect of this article is the discussion of ways in which dictionaries participate in the implementation of language policy. It is indicated that lexicographers make ever so many decisions of a language political nature. In this regard the lexicographical influence of issues like linguistic hegemony and language purism are discussed. Suggestions are also made for future lexicographical procedures.
\end{abstract}

Keywords: COMMUNICATION POLICY, INTERLINGUAL, INTRALINGUAL, LANGUAGE PLANNING, LANGUAGE POLICY, LANGUAGE PROMOTION, LEXICOGRAPHY, LINGUISTIC HEGEMONY, PRESCRIPTIVE, PURISM

Opsomming: Hoe om taalbeleid met woordeboeke te bepaal. Die leksikografiese aanbieding van terme uit die veld van taalbeplanning kort dikwels duidelike en ondubbelsinnige onderskeiding en behoorlike verklaring. Woordeboeke laat te dikwels na om hierdie terme in die lemmalys in te sluit, en sommige kernterme word in geen algemene of vakwoordeboek behandel nie. Hierdie artikel benut resultate van navorsing op die terrrein van taalbeplanning om voorstelle te maak vir die leksikografiese aanbieding en behandeling van ' $n$ aantal relevante terme. Die klem op die onderskeid tussen taalbeleid soos dit toegepas word op die intratalige en intertalige vlak en die motivering van die invoering van die idee van 'n kommunikasiebeleid behoort leksikograwe te help om 'n meer omvattende verslag te bied van terme vanuit hierdie veld en dit sal ook navorsers op die terrein van taalpolitiek bevoordeel. ' $n$ Tweede aspek van hierdie artikel is die bespreking van maniere waarop woordeboeke deelneem aan die implementering van taalpolitiek. Daar word aangedui dat leksikograwe talle besluite van 'n taalpolitieke aard neem. In hierdie verband word die leksikografiese invloed op kwessies soos linguistiese hegemonie en taalpurisme bespreek. Voorstelle word ook gemaak vir toekomstige leksikografiese werkswyses. 
Sleutelwoorde: INTERTALIG, INTRATALIG, KOMMUNIKASIEBELEID, LEKSIKOGRAFIE, LINGUISTIESE HEGEMONIE, PRESKRIPTIEF, PURISME, TAALBELEID, TAALBEPLANNING, TAALBEVORDERING

\section{How to do things with words}

The title of this article is meant as a reference to the title of Austin's well-known book How to Do Things with Words. The title of this book on pragmalinguistics is not only famous; it is also misleading because one necessarily fulfils a speech act when one uses words. Somehow, the title of this article is also partly misleading. In practical lexicography, one can explain the different political motivations behind every single decision, but this does not mean that as a lexicographer one can act without political choices, intended or not. The basic thesis is therefore

Every single lexicographical decision has a language policy relevance and therefore, in the end, a political dimension.

This thesis is not new because the influence of politics on lexicography has often been discussed. However, it usually applies to politically charged words like democracy, terrorist, revolution, black, Negro, racism etc. It is new to regard every lexicographical decision as the result of a political decision, more precisely a language policy decision. Although this is new in lexicography it is not new in the field of language policy (cf. Spolsky 2004: 35). We do not see the lexicographer as "a harmless drudge" who busies himself with tracing the origin and detailing the significance of words, as Dr Johnson and many lexicographers of the last 250 years have underrated themselves. Most lexicographers may be aware of their great influence on language behaviour but fail to realise their influence on cultural and political behaviour. It is also historically unfair to take the present understanding of policy as the only benchmark, although new interpretations in the light of our recent knowledge are required. There is a development that policy is frequently not only used as a term restricted to official or governmental considerations and decisions. The second half of the 20th century saw the formation of a number of new compounds with the lexical item policy as stem, e.g. educational policy, children's policy, women's policy, environmental policy and immigration policy. These new forms are related to key areas in the political decision-making processes of international, national and local authorities. From the late 1980s, the scope of such compounding was broadened to include aspects such as planning and decision-making in companies, organisations, schools and other non-political groups. Examples include senior policy, smoking policy, alcohol policy and stress policy. Along with this development, the scope of older, purely political terms has also been broadened to include planning and decision-making in companies, etc. This devel- 
opment is social as well as linguistic, and it does not just apply to Denmark, Germany, the U.S.A. and South Africa, but as far as we can see to most of the world. The group of new compounds also comprises the terms language policy and communication policy.

One does not find the term communication policy in any contribution to lexicography. Language policy (or the near synonym term language planning) is not a term in the lemma list of most lexicographical dictionaries (e.g. the Nordic Dictionary of Lexicography 1997). The term is not very often mentioned or even regarded as a lexicographical relevant term in the metalexicographical literature (e.g. not at all in Zgusta 1971, Hausmann 1977, Landau 1981, Gouws 1989, Bergenholtz and Tarp 1995, Svensén 1993, Wiegand 1998, Gouws and Prinsloo 2005), and is only mentioned twice in the comprehensive three-volume International Encyclopaedia of Lexicography (1989-1991), and in both cases not as a real subject of discussion. Of course we have papers and monographs on politically problematic words and quotations in dictionaries and even dictionaries with such words, e.g. Strauß, Haß and Harras (1989) and Zeitgeschichtliches Wörterbuch (2003). We are dealing with the most obvious example indicating that language is narrowly connected with power, including political power. One can practise politics by means of words. With words one can describe facts in such a way that the factual contents become blurred. Words can also be used or misused in such a way in a given historical context that they fall into disrepute for a long time or even permanently. The non-use of specific words that would actually have been more apt could be part of a conscious political strategy. This is an old strategy, which will continue to be used. Typical examples are: Who is a terrorist and who is a freedom fighter? Is one an anti-Semite when as a non-Jew one criticises some decisions of the Israeli government? Should one refrain from using the word nigger in favour of coloured? Is it only politically correct language use to refer to a woman as sex worker and not as prostitute? This strategy is especially employed in political classifications, directed at race, sexuality, sex, ecology and the mental state of a person.

In all these cases, we are dealing with loaded political words that could also fall within the scope of a language policy. They regard controversial political or socio-political expressions, discussed in many metalexicographical contributions. This is typically done by examining a selection of dictionaries to determine how good or bad, politically correct or incorrect they are or whether certain words have at all been included in their lemma list. In current public discussion such words are the most obvious examples for language policy decisions in lexicography. However, this is only a small part of the problem; only one out of three in the proposed classification of intralingual language policy.

In general we want to achieve two aims in this contribution. Firstly, we want to introduce some terminological proposals from Bergenholtz (2006) to lexicography and, secondly, we want to show where and to what extent language policy plays a role in lexicography. 


\section{What is language policy?}

In at least one sense the above-expounded view in lexicographical textbooks is incomplete: In contributions to all kinds of language regulations language policy is not the only term used. In English-speaking countries especially, the term language planning, introduced by Haugen (1959), is more often employed. In addition, other terms are sometimes used synonymously, or for special kinds of 'language regulations', e.g. in English language engineering, glottopolitics, language development, language regulation and language management; in German Sprachlenkung, Sprachpflege, Sprachreinigung; and in Afrikaans taalbeplanning, taalbeleid and taalpolitiek. We will not try to give a terminological overview (for this see Bergenholtz 2006). It is confusing enough when one only considers the use of the three main terms language policy, language planning and communication policy.

\subsection{Explanations in dictionaries}

Most general language dictionaries do not include the above-mentioned terms in their lemma list. Communication policy is not found at all, and language policy (or the respective equivalents) and language planning only in a few German, Dutch, Danish and Afrikaans dictionaries. It is interesting to note the absence of these terms in the majority of English dictionaries.

Regarding German it is actually only two dictionaries that include the term Sprachpolitik, i.e. the three editions of Duden-GWB and the Brockhaus-Wahrig 1980-1984. It is surprising that more comprehensive dictionaries like Wahrig 2000, Duden-Universalwörterbuch 2003 or Bünting and Karatas 1996 do not include this word as a lemma. Taking the proper and precise lemma selection of these dictionaries into account, one can conclude that Sprachpolitik does not belong to the 100000 most important German words. In Duden-GWB ${ }^{1}$ and almost identically in Brockhaus-Wahrig 1984 the following item is found:

(1) Sprachpolitik staatliche Maßnahmen in Hinblick auf eine Sprache (Duden-GWB ${ }^{1}$ 1981)

[Language policy governmental regulations regarding a language]

Firstly, it refers to governmental regulations and therefore national and not international or non-governmental language regulations. Secondly it refers to one, and not more than one language or else the lexicographers would have written "regarding one or more languages". The next two editions give completely different information. The preparation of a new edition of a dictionary often, but not always, leads to changes that are improvements. With identical items, the changes in the case of Duden-GWB2 and Duden-GWB3, are not improvements. Syntactically the explanation has been constructed in such a way that one can only try to guess the contents: 
(2) Sprachpolitik die in einem Land gesprochene[n] Sprache[n], die in einem Land sich stellende Sprachenfrage o.ä. betreffende Politik (Duden-GWB3 1999)

[Language policy the language(s) spoken in a country, the prevailing language or similar issues in a country regarding politics.]

When one assumes that both parts of the explanation need to be amplified, as elsewhere in this dictionary, one realizes that "the language(s) spoken in a country regarding politics" refer(s) to a national political matter with regard to either one or more languages. This corresponds to the item in Duden-GWB ${ }^{1}$ with this change, however, that it now regards not only one, but more than one language. It probably still deals with a national and not an international matter and not with private but with public decisions, else it would have read: "in a country, in an international or national organisation as well as in private or public companies or institutions". It is not clear exactly what the language policy wants to influence regarding one or more than one language. It could refer to linguistic purism or linguistic norms, or it could refer to the prohibition of other languages or prescriptions for the official use or promotion of one or more languages. To be able to understand the second part of the explanation "the prevailing language or similar issues in a country regarding politics" one should know what language issues are. This term is explained as follows in Duden-GWB2 and Duden-GWB3:

(3) Sprachenfrage aus dem Zusammenleben mehrerer ethnischer Gruppen mit verschiedenen Sprachen innerhalb eines Staates herrührende Problematik (Duden$G W B^{3} 1999$ )

[Language issues problems arising from the living together of various ethnic groups with different languages within one country]

The not so industrious user who does not look for Sprachenfrage (language issues) will be unable to guess that Sprachpolitik (language policy) specifically deals with the relation between languages spoken by different ethnic groups in one country. It can be seen that the explanation given in Duden-GWB ${ }^{1}$ is also complemented in the sense that language policy does not only refer to more than one language, but also to more than one language of members of different ethnic groups. This does not really improve our understanding of the term. One can assume that language policy is not a central theme in Germany and that the unclear explanation reflects the little public interest and consequently the unclear debate.

In the domain of language policy one in reality finds, with the exception of France, no comprehensive debate in the bigger European countries like Germany, England, Spain and Italy. The situation is different in smaller countries like Switzerland, Austria and especially in the Scandinavian countries. One can only suspect the reasons. We believe there are at least two reasons: The one reason is that the big countries, and that also means the big languages, in the 
European Union are increasingly gaining influence to the detriment of smaller countries and smaller languages. Consequently these countries see the necessity for language political initiatives to maintain the current status of the linguistic diversity, as prescribed by the EU (Article 22 of the Charter of Constitutional Rights of the European Union), and not to let it be undermined any further. On the one hand Germany supports the small and medium countries but would like to see German, as the biggest language in the EU, also reaching the status which English and French have in practice. To follow both directions at the same time is not likely to succeed. The other reason is connected with cultural tradition regarding official language regulations. A few countries like Spain and France have in principle a long tradition of a positive attitude towards prescriptive regulations. In practice, however, the interest lies much more in general regulations and not as much in details and the implementation of sanctions for not complying with regulations. However, since 1990, the development in France follows a more descriptive direction by allowing new orthographical and inflexional morphological variants. The Nordic countries, especially Iceland, the Faeroe Islands and Norway, have another tradition. Contrary to southern Europe, governmental language interventions for changes in existing language usage are implemented here by official decisions and supported by public control.

In Holland and South Africa, as in English-speaking countries, the term language planning and its equivalents are frequently used. In Afrikaans, the term taalbeleid is also quite often employed.

(4) taalbeplanning Beplanning in staatkundige verband van geleenthede om 'n taal binne groepsverband of in die land as geheel te gebruik (Verklarende Afrikaanse Woordeboek 1993)

[language planning Planning in political context for opportunities to use a language in communal context or in the country as a whole]

We are dealing here with an intralingual relation and with planned opportunities within a language. It should be noted that it is considered a public matter. The term language planning is used in accordance with its original use (Haugen 1959), but not exactly as in current scientific contributions to language planning and language politics. Language policy is appropriately described as an interlingual matter:

(5) taalpolitiek Politieke beleid t.o.v. die tale wat in 'n meertalige staat gebruik word (Verklarende Afrikaanse Woordeboek 1993)

[language politics Governmental policy with regard to languages used in a multilingual state]

Whether this explanation has been taken from the Dutch Van Dale dictionary can only be presumed: 
(6) taalpolitiek politiek die gevoerd wordt ter bescherming of onderdrukking van een taal, vooral in een staat met meer dan één taal (Van Dale Groot Woordenboek der Nederlandse Taal 1999)

[language politics Policy followed for the protection or oppression of a language, especially in a state with more than one language]

These two entries can hardly be regarded as correct. Had this been the case, monolingual countries would typically not have had a language policy or the need for such a policy. Regarding all the differences in the definitions in scientific contributions and technical dictionaries, this division and classification of interlingual language politics and intralingual language planning is quite special. This distinction is elsewhere found only in Hartmann and James (1998), one of the four existing lexicographical dictionaries. The division into interand intralingual regulations is important and correct but the terminological classification is not in accordance with the theoretical and practical standard. It would be more accurate to have a division of language policy or language planning in inter- or intralingual language regulations as in the Danish Internet Dictionary where language policy and language planning are regarded as synonyms, but with language policy being the preferred term:

(7) sprogpolitik

1. valg af et eller flere sprog og hermed også fravalg af et eller flere andre sprog

2. valg og hermed også fravalg af bestemte stilmidler, regler, ord eller ordformer i et sprog (Den Danske Netordbog 2004)

[language policy

1. selection of one or of more languages, that also means the voting out of one or more languages

2. selection and so also the voting out of certain styles, grammatical rules, words or inflections or spellings within a language]

However, this explanation is not in full accordance with the standard, where language planning is often regarded as the superordinate and language policy as the subordinate term. This often prevails as a result of the opinion that language planning describes and develops generic theories and methods whereas language policy is the implementation of language planning, as seen in the following articles from a didactic dictionary:

(8) language planning planning, usually by a government or government agency, concerning choice of national or official language(s), ways of spreading the use of a language, spelling reform, the addition of new words to language and other language problems. Through language planning, an official language policy is established and/or implemented. (Richards, Platt and Platt 1992: 203)

(9) language policy see language planning. (Richards, Platt and Platt 1992: 203) 
But in the end theoretical contributions and specialized dictionaries also give a confusing picture. This field has a need for applying its own aims and methods to its own terminology, e.g. a linguistic dictionary distinguishing between language planning as an intralingual regulation by someone and language policy as an inter- and intralingual language regulation with official government participation:

\section{(10) language planning}

(also language engineering) Making deliberate decisions about the form of a language, such as choosing among competing forms and inventing new vocabulary. This is most often carried out on some kind of official basis. (Trask 1997: 127)

(11) language policy

An official government policy regulating the form, teaching or use of one or more languages within the area controlled by that government. (Trask 1997: 127)

\subsection{Cultural and scientific habits}

Terms like language planning, language policy and language politics have often been used in a haphazard way and very seldom has a distinction been made between e.g. language policy and communication policy. The latter term should be more often introduced to cover an extensive domain in the language-planning field. Linguists should develop the habit of using these terms in a well-defined way.

\section{Different terminology in different languages}

One of the real problems in the discussion of language policy is the lack of a standardised terminology. This does not only apply to the intralingual level but especially to the interlingual level. As a result, confusion easily prevails, causing participants in the scientific discussion often to be unsure whether their use of a given term will be interpreted unambiguously. Confused users will not really find clarity in dictionaries. The English terms language policy and language politics may in some environments perhaps be regarded as synonyms (cf. their presentation as translation equivalents of the Dutch word taalpolitiek in the Van Dale Groot Woordenboek Nederlands-Engels). However, this does not imply that for instance their Afrikaans equivalents taalpolitiek and taalbeleid are used as synonyms. Linguists working in the field of language policy should make a serious attempt to ensure the standardisation of terminology, which should be reflected in dictionaries. Terms from the semantic field of language policy and language planning are often used in communication situations between subject-field experts and laypersons (cf. Bergenholtz and Tarp 1995). These terms should therefore be reflected not only in dictionaries dealing with languages 
for special purposes but also in dictionaries dealing with language for general purposes.

\section{Who plans what for whom and how and why?}

In a language-sensitive environment there may well be a variety of language policies, ranging from the official language policy for a given country or speech community to language policies for specific institutions like schools, universities, companies, church congregations, etc. The official policy may be a political decision taken by a national government, whereas other policies may be formulated by the respective institutions. A publishing house may have its own policy regarding the language usage in its publications. Dictionaries often reflect an existing language policy, e.g. the orthography laid down by an official body, but dictionaries can also impose a biased approach on the language use of a publishing house or a lexicographer.

Language policy is directed at different communication types (e.g. lingual or non-lingual), communication channels (TV, radio, newspapers, e-mails) and communication venues (meetings, assemblies) (cf. Bergenholtz 2006).

A language policy, usually introduced by means of prescriptive rules or a language plan, should always be directed at a specific target group which may range from all the citizens of a country to a small group of people being members of a specific institution. The language policy will concern the outgoing communication of the target group or the institute-internal communication occurring between members of the group. A typical example could be the language policy of the University of Stellenbosch. This policy has led to a language plan, which gives directives to staff and students regarding the use of Afrikaans and English, especially in the lecture-hall environment. The formulation of a language plan has to be seen as one of the results of a language policy.

\subsection{Different types of communication and language policies}

The preceding discussion and the following definitions are meant for the metalevel, i.e. the scientific discussion of the fields of communication policy and language policy (or language planning). Under the recommended terms we have listed expressions, which seem to be synonymous with our preferred term. The distinction between the theory and the real and concrete communication policies is reflected in some of these proposals as theory of language planning versus language planning (Tauli 1974: 56) or language planning versus language policy, in the sense of Fettes (1997: 14). The most convincing terminological use seems to be the distinction between language policy and language plan (Language Policy and Plan for South Africa 2000). In international terminology, however, one does not find such a clear distinction. Language policy is used for the theory and methodology and the results are also called language policy. We 
want to propose that the terminological use of language plan should be adopted for the results, and language policy or language planning for the theory. The sum of all kinds of communication and language policies should be called communication and language plan.

Terminological entries can serve different functions. We have to distinguish between different types of users, different assumptions and different user situations. For a successful reception of texts on language policy, we need to take into account as many frequently used terms as possible, in the following indicated as synonyms by means of an equal-sign. For experts in the field of language policy, the theoretically-systematically formed terms are recommended. For laypeople and for semi-experts, i.e. for experts in fields other than language policy (lexicographers, politicians, sociologists, etc.), we recommend other terms: those formed not quite so systematically but rather tending to be transparent and comprehensible without fully having to understand the theoretical background. Therefore the term specific intralingual language policy is recommended for theoretical contributions to language policy, while the synonym term linguistic units selecting language policy is recommended for laypeople and experts in other fields than language policy. In some cases only one term is recommended for both user groups, e.g. communication policy:

general communication policy (this term is generally recommended)

$=$ general language policy

= general language planning

A general communication policy involves the deliberate control of an organisation's internal and external communication in order to optimise the functionality of the organisation, including its product development and sales. Usually, a communication policy takes into account the values and visions of the organisation concerned. A general communication policy is language-independent and is usually issued by, and applies to, companies, organisations or sub-national authorities.

Language-independent general communication policies may also be issued by large, international organisations, such as the UN, the EU and NATO. In some cases, however, such a policy may also apply to an entire state, as can be seen in the case of certain African countries, such as Senegal and Tanzania (Bathily 2005; Tanzania 1997). International organisations and large companies often include a general description of their basic values in their language policies. Normally, however, the term communication policy does not include consideration of the value system entrenched in the company's or organisation's language policy.

The result of a general communication policy should be called general communication plan.

specific communication policy (this term is generally recommended)

$=$ specific language policy

$=$ specific language planning

A specific communication policy involves general or thematic requirements or prohibitions concerning particular forms or channels of communication or a 
prohibition against acquiring particular information or documents. Such prohibitions include requirements concerning general or limited access to, or use of, specific types of information.

Parts of a specific communication policy may not only apply to employees of the organisation or authority involved, but also, or solely, to enquiries made by customers or citizens. Thus, communication policy differs from language policy, which is always directed at the internal or external communication of employees, members or students. Whereas a general communication policy rarely applies to states, several examples of specific communication policies on a state level can be found, particularly in dictatorships. Such communication policies may include the prohibition of flyers, phone calls to foreign countries or use of the Internet. Examples of such communication policies can also be found in some existing language policies.

The result of a specific communication policy should be called specific communication plan.

interlingual communication policy

$\rightarrow$ interlingual language policy

\section{intralingual communication policy}

$\rightarrow$ intralingual language policy

Along with this definition of communication policy, we arrive at a definition of the term language policy (and language planning) that should be free from the flaws and inadequacies inherent in the afore-mentioned definition. Simultaneously a number of synonyms will be listed in accordance with the terminology used in various theories and practices. It should be noted, however, that many language policies contain elements, which we have classified as being part of a communication policy. In such language policies, these elements form an intrinsic part of the language policy, taking one of the following two forms:

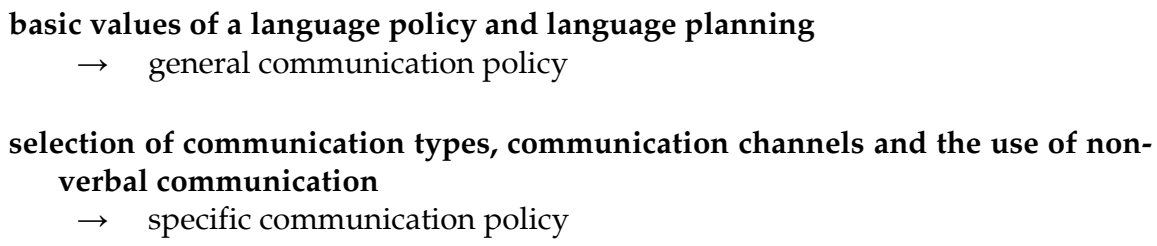

Despite this being the case, the terms language policy (or language planning) and communication policy may concern the promotion of different verbal and nonverbal languages. Whereas communication policy may also include guidelines on the selection and use of non-verbal languages, the term language policy (or language planning) refers solely to the selection and use of verbal communication forms in different contexts and may therefore be defined as follows:

language policy (this term is generally recommended) $=$ language planning 
Language policy, which refers to the deliberate control of issues pertaining to language, concerns relationships between languages, consisting of interlingual relations, on the one hand, and issues specific to one language, consisting of intralingual concerns, on the other. Though a language policy may form part of a communication policy, the existence of a communication policy is not a prerequisite for the existence of a language policy.

The result of a language policy should be called a language plan.

interlingual language policy (this term is recommended for theoretical contributions to language policy)

$=$ language selection and promotion (this term is recommended for contributions for laymen and for experts in other fields than language policy)

$=$ status planning

$=$ interlingual communication policy

An interlingual language policy is the clear and deliberate choice, recommendation or promotion of one or more language(s).

The result of an interlingual language policy should be called an interlingual language plan.

general interlingual language policy (this term is recommended for theoretical contributions to language policy)

= language selection (this term is recommended for contributions for laymen and for experts in other fields than language policy)

$=$ general interlingual language planning

$=$ status planning

= general language policy

A general interlingual language policy involves language selection, entailing the selection of certain languages at the expense of others. This type of selection concerns not only a choice of which languages are to be used in communication, but also which languages are chosen as subjects in schools and universities.

The result of a general interlingual language policy should be called a general interlingual language plan. A language plan such as this could result in the production of bilingual or polylingual dictionaries in the selected or supported languages.

specific interlingual language policy (this term is recommended for theoretical contributions to language policy)

= language promotion (this term is recommended for contributions for laymen and for experts in other fields than language policy)

$=$ specific interlingual language planning

$=$ status planning

A specific interlingual language policy serves as a protectionist language policy that prescribes the promotion of one or more language(s), either by means of language-directed legislation or by means of financial and political support for selected organisations that promote a particular language or culture. Language-directed legislation concerning both lingual and non-lingual languages, primarily apply within the country that promulgates the legislation in ques- 
tion. Organisations promoting a particular language or culture are supported in order to promote or increase the knowledge and use of the language in question, primarily in foreign countries.

The result of a specific interlingual language policy should be called a specific interlingual language plan. The result of such a language plan can be the production of bilingual or polylingual dictionaries in the selected or supported languages.

special form of specific interlingual language policy (this term is recommended for theoretical contributions to language policy)

= linguistic hegemony (this term is recommended for contributions for laymen and for experts in other fields than language policy)

$=$ special form of interlingual language planning

A special form of specific interlingual language policy is a hegemonic language policy, involving an opposition to one or more language(s) in favour of one or more other language(s).

The result of a specific form of interlingual language policy should be called a special form of interlingual language plan.

intralingual language policy (this term is recommended for theoretical contributions to language policy)

= style and linguistic units selecting language policy (this term is recommended for contributions for laymen and for experts in other fields than language policy)

= intralingual language planning

An intralingual language policy is the choice or recommendation of, the warning against, or the banning of certain linguistic constructions, collocations, phrases or words in a particular language.

The result of an intralingual language policy should be called an intralingual language plan.

general intralingual language policy (this term is recommended for theoretical contributions to language policy)

= style selecting language policy (this term is recommended for contributions for laymen and for experts in other fields than language policy)

$=$ general intralingual language planning

$=$ communication-optimising language policy

$=$ language guide

= manual of style

= style book

= language hygiene

A general intralingual language policy involves stylistic selection, meaning a clear and deliberate choice or recommendation of specific stylistic aspects or rules pertaining to a particular language.

The result of a general intralingual language policy should be called a general intralingual language plan. A general intralingual language plan may result in the production of style guides or handbooks for language use. 
specific intralingual language policy (this term is recommended for theoretical contributions to language policy)

= linguistic units selecting language policy (this term is recommended for contributions for laymen and for experts in other fields than language policy)

$=$ specific intralingual language planning

$=$ prescriptive linguistics

$=$ language hygiene

$=$ corpus planning

A specific intralingual language policy involves the selection of linguistic units, meaning a clear and deliberate choice or recommendation regarding specific grammatical constructions, words or word forms in a particular language.

The result of a specific intralingual language policy should be called a specific intralingual language plan. Such a language policy may result in the production of dictionaries or grammars.

special form of specific intralingual language policy (this term is recommended for theoretical contributions to language policy)

$=$ puristic language policy (this term is recommended for contributions for laymen and for experts in other fields than language policy)

$=$ special form of intralingual language planning

$=$ purism

$=$ ideological language policy

$=$ language hygiene

A special form of specific intralingual language policy is a puristic language policy based on a particular historical, moral or political perception of proper language, which results in the prohibition of, or opposition to, certain grammatical constructions, words or word forms in a particular language.

The result of a special form of specific intralingual language policy should be called a special form of intralingual language plan. Such a language policy may result in the production of handbooks or specialised dictionaries.

\section{Communication policy and lexicography}

In the following sections we will give some comments on the relations between the different kinds of communication and language policy and lexicography. For every term from the above list one could write a separate contribution. We will therefore only give some general comments with examples from some concrete language policies. According to the preceding argumentation, we will use the terms for semi-experts and laypeople, i.e. in relation to the field of language policy for lexicographers.

\subsection{General communication policy}

What we call "general communication policy", i.e. the incorporation of values for decisions for a nation, an organisation, a company, a family or an individual, is the main topic in those policies usually called "communication policy", 
but values (or visions and missions) are also part of the theoretical discussion of language policy and are part of many language policy plans:

This language policy is intended as an enabling framework for promoting South Africa's linguistic diversity and encouraging respect for language rights within the policy framework of building and consolidating a united democratic South African nation. (Language Policy and Plan for South Africa, 1.1)

This is a very general vision using a language policy for the consolidation of democracy or, more realistically, a step to a more democratic South Africa. In the end the choice of - only - 11 languages is not a fully democratic selection because of the omission of languages like Khoi, San, and commonly used languages like Hindi, Arabic, Tamil, etc. More concrete is the clear wish to promote and create conditions for the development and use of all official languages (The Language Plan Task Group (LANGTAG) 1996 Chapter 1, section 5, cf. Kamwangamalu 2004: 262). In the current discussion in contributions to interlingual language policy one finds a focus on or a restriction to government decisions, e.g. Webb (2002: 40). This is too narrow and also a contradiction in the practice of language policies where values are a prerequisite for every communication and language policy plan on all levels.

Democracy as the main value is not only a question of support for language diversity, but also for an easy and easily understandable language use, as it is claimed in the latest Swedish governmental proposal for a language policy:

En levande demokrati, där medborgarna deltar i det offentliga samtalet och kan göra sina röster hörda, förutsätter klara och begripliga myndighetstexter. Detta ökar också rättssäkerheten och bidrar till ökad effektivitet i förvaltningen. (Swedish Governmental Proposal 2005: 1)

[A living democracy with an active participation in the public discussion of all citizens needs clear and easily understandable official texts. Such a communication will more efficiently increase the legal security and support in the administration.]

It may be difficult to define the exact borderline between values as a part of a general communication policy and the linguistic units selecting language policy as part of the intralingual policy. We consider the view "influence two dialects minimizing the differences between them" as being a value or a political wish for equalizing differences in a language community. This has been the case in the official language policy in Norway regarding Nynorsk and Bokmaal for the last 50 years until 2005 when the Norwegian language council took the decision to promote the differences between the two official dialects (Norwegian Language Council 2005). If this decision is not reversed within the next 100 or 200 years, we can expect to have two languages in Norway and not two dialects as at present. This example is extraordinary because in almost all intralingual policies the selected value(s) is (are) the same as that in Norway before, and the opposite of that after 2005. 
One kind of value selection known from linguistic discussions will - if it is chosen - be a value leading to no language policy: Leave the language alone! This post-behaviouristic, almost religious credo claims that every language change is "natural" and non-natural changes are manipulative:

For change that comes spontaneously from below, or within, our policy should be, Let your language alone, and leave its speakers alone! But other forms of language manipulation have other origins, other motives, other effects, and are far more dangerous. (Lakoff 1990: 298)

To this anticommunicative and language-political statement Cameron (1995: 20) begins to give the right answer, formulated as a question: Why is spontaneity the only value? How about truth, beauty, logic, utility? We are not sure that Cameron's possible values are the most important ones for policies. The choice of and arguments for every value as pre-condition for language policies has to be discussed separately. For every kind of communication and language policy one has quite different values: for communication policies see Kotler and Keller (2006: 534-562), for interlingual language policies see Webb (2002: 39f), and for intralingual language policies see Bergenholtz et al. (2003). Both interlingual and intralingual policy values (democracy, the creation of conditions for the development of language(s), more effective communication, etc.) invites among other decisions a discussion of the needed dictionaries for a specific nation according to its specific social conditions.

\subsection{Specific communication policy}

Traditionally we only discuss the need for printed language dictionaries. We have to add to it the need for sign-language dictionaries and access to such dictionaries, as well as language dictionaries on the Internet. The choice between paper and electronic dictionaries concerns not only governmental, but also personal and organisational decisions to determine whether the access to Internet lexicographical tools gets priority, partial priority or no priority. An estimate of the number of Internet dictionaries shows more than 100000 (cf. <www. yourdictionary.com>). Many of these dictionaries are developed by individuals or produced by companies or universities. Only a minority has government support. On the given homepage we find very big differences between the large languages, which means between the 100 largest languages in the world. The largest languages (Chinese, English, Russian, German, and Spanish) have many dictionaries. In some cases one cannot explain the differences between languages in terms of the respective number of native speakers or their being well documented and standardised or even their status as official languages. Sometimes differences exist between languages spoken in the Third World, but this is not the full explanation, e.g. Somali has four dictionaries compared to the six of Dutch in the yourdictionary list. It is also not only a question of languages with many or few native speakers. Faeroese, with 45000 native speakers, has 
three dictionaries, almost the same as Afrikaans with four Internet dictionaries and more than six million native speakers. Also with regard to three welldocumented languages, all in the top-200 list of the largest languages in the world, the medium of the Internet dictionary is used in varying degrees:

- Catalan has 6,7 million native speakers and five million second-language speakers (1996). With Spanish the national language in Spain, Catalan is only one of the official languages in parts of Spain. The collection of Catalan Internet dictionaries on <www.yourdictionary.com $>$ nevertheless comprises 29 titles, among which 22 are specialized language dictionaries.

- Danish, the only official language in Denmark, has six million native speakers (2006). For Danish we find 17 dictionaries in the above-mentioned dictionary bank.

- Afrikaans has six million native speakers and 10,3 million second-language speakers (1996). It is one of the 11 official languages in South Africa. For Afrikaans we find only four titles, three English-Afrikaans dictionaries and one specialized language dictionary, but surprisingly no monolingual dictionary.

The difference between Danish and Catalan (the latter not being an official national language) on the one side and Afrikaans as an official language on the other is significant. One explanation could be that the fight for Catalan in Catalonia (a province in Spain) is so intensive, that the local government, local universities, local organisations and single individuals spend time and money on developing dictionaries as part of the fight for their language. Such considerations could and should be made for many more languages. Internet dictionaries will become still more important in future.

\section{Language policy and lexicography}

The main distinction made in this article is between inter- and intralingual language policy. It does not mean that one has to discuss bilingual lexicography only as part of interlingual language policy. Bilingual dictionaries are also a topic for intralingual decisions concerning the choice of linguistic units for the language in bi- or polylingual dictionaries (cf. par. 4.5-4.6).

\subsection{Language selection}

It would be unrealistic to plan the development of different dictionaries for every lexicographical function for every language. Even attempting to compile 
only a polyfunctional dictionary (cf. Bergenholtz 1997 and Gouws and Prinsloo 2005: 54f) for every language would be difficult or even impossible to achieve. It is not only a question of money (cf. the example from Greenland in the next section). If we assume that we have about 6800 languages in the world, we can make the following calculation: For every language one needs at least one general language dictionary, at least one general encyclopaedia, at least 150 different specialized dictionaries, e.g. a spelling, synonymy, collocation, idiom, proverb dictionary, etc. etc., an accounting, gene technology, computer dictionary, etc. etc. Furthermore we need at least two bilingual dictionaries for every language pair (L1 $\rightarrow \mathrm{L} 2$ and L2 $\rightarrow$ L1 $(6800 \times 2=13600)$ and the same for the single specialized fields (accounting, computer science, etc.). A quite conservative assumption gives us at least 100 different fields or $100 \times 6800 \times 2=$ 1360000 ). For each of the estimated 6800 languages in the world one needs at least

1 monolingual general language dictionary,

1 monolingual general encyclopaedia,

150 monolingual specialized dictionaries,

13600 bilingual general language dictionaries, and

1360000 bilingual specialized dictionaries.

For the 11 official languages in South Africa the number of "needed" dictionaries almost equals the total population of the country. We could proceed with the same speculative calculation for all the languages in the world and will come to the same result: Dictionaries are important tools helping people with some kind of communication and knowledge problems, but we will never reach the ideal number of needed dictionaries. Some potential dictionaries will have so few users that it would not be worth the effort trying to produce them. We therefore have to decide which dictionary types for which languages and language pairs should be supported, if the market mechanism, i.e. the number of sold paper dictionaries or subscribers for Internet dictionaries, cannot pay for the necessary theoretical and practical lexicographical work.

We also have to decide which dialect is to be chosen as the standard for a certain language in a certain dictionary. This topic cannot be treated here, but it must be stated that the concrete decision is to be made as part of the specific intralingual policy (see par. 4.5).

Another language selection decision to be made is the choice of the explanation language, especially in bilingual dictionaries, and the choice of language for the outer texts (preface, user guide, dictionary grammar, etc.). This decision should be motivated by selected dictionary functions for the specific dictionary (cf. Bergenholtz and Tarp 2003). But the lexicographer (or the government or the organisation paying for the lexicographical work) could also have language policy considerations of overriding importance. During the planning of the Malagasy-Aleman Dictionary (1991) it was proposed from governmental side that the outer texts should be written in Malagasy, German and also French. 
The reason for this proposal was that the language of instruction in many high schools is French - also for teaching German. As a matter of fact, most teachers and pupils are not used to Malagasy grammar and other Malagasy linguistic terms. They of course understand and use their mother language, but not as language of instruction. Although Henning Bergenholtz, as director of the lexicography project, had to agree to the correctness of this description of the language situation and the arguments for French as one of three dictionary explanation languages, he did not follow the proposition because he and other members of the research group pleaded for another language policy with a broader use of Malagasy as language of instruction. Such decisions for the selection of the dictionary explanation language or language pair are not unique to Madagascar but are necessary in many countries where bilingual dictionaries are to be compiled in polylingual communities.

\subsection{Language promotion}

In the 500-year-old history of printed dictionaries and also in the very short history of Internet dictionaries, many dictionaries could not have been produced if there had not been governmental or private promotion of the dictionary or lexicography centre. Money and trained lexicographers are needed. These needs are often referred to in theoretical discussions, e.g. by Lopes (2004: 185) and Kamvangamalu (2004: 62), but they are also part of national language policies, e.g. in the Danish Cultural Ministry's Sprog på spil 2003, the Swedish Governmental proposal (2005: 7ff) or the Pan South African Language Board (About South Africa 2005). The real need for money and the financial planning of lexicographical projects are not often the subject of scientific publications. It is a desideratum when one considers that big national monolingual dictionaries using large amounts of money for many years in long-term projects, as for the Woordeboek van die Afrikaanse Taal in South Africa (since 1926 and not finished yet), the Norsk Ordbok in Norway (since 1930 and not finished yet, cf. Bergenholtz 1996) or the Svensk Akademiens Ordbock (cf. Bergenholtz and Malmgren 2000). The latter dictionary project started in 1892 and 115 years later the editorial team is now working on the letter $\mathrm{T}$, having had a budget with a current value of approximately 1000000000 SEK or 100000000 Euro. One of the few publications on the topic of planning the costs for small and larger dictionary projects is the publication Lexicography as a Financial Asset (1996) in which many of the contributions surprisingly speaks more about the education of and need for lexicographers and not much about the financing and the calculation of expenses, e.g. Alexander 1996, Mini 1996, Prinsloo 1996a, 1996b and Gouws 1996. However, in some ways it might be the right point to start. As a matter of fact: Money is not enough. The education of lexicographers is a primary prerequisite for dictionary-making. To prove this we may use the example of the development of a Greenlandic monolingual dictionary. In 1978 Greenland's Provincial Council proposed the compilation of such a dictionary, for which 
the government granted about 7000000 DEK (in today's value approximately 2000000 Euro). The project "Ordbogersuaq" started with meetings and discussions, spending about half a million crowns on refreshments (cf. Langgård 1997). After some years the rest of the money was returned to the government because the dictionary planners, being unacquainted with lexicography, did not succeed in drawing up any real schemes for or making any real progress with the dictionary.

\subsection{Linguistic hegemony}

Linguistic hegemony, as a special form of interlingual language policy, can influence lexicography in a bi- or multilingual community where all languages do not have the same official status or recognition as preferred language. Dictionaries can be influenced by having to reflect this situation or they can reflect a view independent of the hegemonic approach.

In Gabon, a multilingual country with 62 indigenous languages, French is the only official language. Since 1994, a much more lenient approach exists towards the indigenous languages seeing that the revised constitution states that the national languages should be promoted and protected. Until then French had not only been the sole official language but it had also been imposed as the only allowed language of communication, e.g. in the educational system. This ruling refers to the language of instruction as well as to the general communication system in schools. Strict rules were enforced to forbid learners using any language but French on the school grounds and where learners trespassed they were punished (cf. Mavoungou 2002). This language policy has been detrimental to the development of lexicography in Gabon. There was no realisation of the need for the compilation of French dictionaries because users could rely on French dictionaries compiled in France. Even though a new variety of French, i.e. Gabonese French, emerged in Gabon, the hegemony of the language of colonisation eschewed the need for a lexicographical acknowledgement of this new variety. The French dictionaries being used in schools, in public life and in households presented a variety of French not fully reflecting the day-to-day language use of the Gabonese speech communities. The position of the indigenous languages was much worse. Due to the lack of any official recognition, and the dominance and hegemony of French there was no support for lexicographical projects in any of the indigenous languages. Language policy impeded lexicographical activities in the indigenous languages and led to a situation where the official language was lexicographically represented in a super-standard not fully reflecting the real language usage.

In spite of the language policy some bilingual dictionaries with French and an indigenous language were compiled. If the remarks of Gallardo (1980: 61) that "in non-standardized language situations, dictionaries do not exist or, at best, are bilingual dictionaries, that is, compiled in function of a different 
language" are considered, this compilation of bilingual dictionaries combining French with an indigenous language may seem the proper way to follow. However, the genuine purpose of these dictionaries was not to promote the relevant indigenous language or to give its speech community a source of reference. Nyangone Assam and Mavoungou (2000: 269) clearly state that most of the Gabonese bilingual dictionaries dealing with French and an indigenous language, are biased towards French. They emphasise the major role of missionaries and colonial administrators in the compilation of Gabonese dictionaries. Their overview of Gabonese lexicography leads them to remark: "As far as dictionary purposes are concerned, most earlier dictionaries were compiled to help European traders and explorers to communicate in Gabonese languages. They were also useful aids for Christian evangelisation and French colonial administration." (2000: 269).

The situation in Gabon was not unfamiliar, for similar situations prevailed in many other African countries. Kidda Awak (1990: 10) states that many dictionaries in Africa were not compiled for use by Africans but to assist the European explorers as expeditionary guides or to help missionaries in learning the African languages for evangelisation purposes.

Gouws (2005) makes a distinction between externally-motivated and internally-motivated lexicographical endeavours in Africa. Externally-motivated dictionaries are usually bilingual products, co-ordinating a local African language with a European language, typically the first language of the missionaries or the colonisation officials. The compilers of these products are not speakers of the local language but rather of the language of colonisation. Internallymotivated lexicographical endeavours are the dictionaries compiled from within the given speech community. Externally-motivated lexicographical endeavours often are the results of a prevailing language policy that protects the hegemony of the language of colonisation.

Lexicography in Africa gives evidence of varying forms of the influence of linguistic hegemony or attempted linguistic hegemony. In this regard externally-motivated dictionaries played a significant role. For many years during the nineteenth century English was the only official language of the Cape Province in South Africa. Since the late seventeenth century, Afrikaans had already been a divergent dialect of Dutch (cf. Gouws and Ponelis 1992). The early development of Afrikaans occurred in a pre-lexicographical environment and colonial Dutch received scant lexicographical attention (cf. Gouws and Ponelis 1992: 81). The emerging Afrikaans showed increasing differences from the then standard Dutch as used in the Netherlands. Although Dutch was no longer an official language in South Africa, there was a definite Dutch interest in the linguistic situation in South Africa, an interest that illustrates a form of distant linguistic hegemony. In 1831 the Dutch scholar A.N.E. Changuion came to South Africa as professor in classic and modern languages, especially Dutch literature (cf. Van der Merwe 1971). In 1844 he published his well-known book De Nederduitsche taal in Zuid-Afrika hersteld, zijnde eene handleiding tot de kennis 
dier taal, naar de plaatselijke behoefte van het land gewijzigd. His intention with this book was to give Dutch such a firm base in the Cape that Afrikaans could make no progress. This book contained a back-matter text "Proeve van Kaapsch taaleigen", one of the first dictionaries treating Afrikaans. In the preface Changuion said that the practical aim of this dictionary was to rid Dutch, spoken in South Africa, from the "corrupt" words and expressions that he encountered in South Africa, signalling the beginning of the new language, Afrikaans. This external motivation was a typical Euro-centred approach to African lexicography and an attempt to maintain linguistic hegemony, although from a distance.

Some externally-motivated dictionaries had also been compiled to benefit the local language of African speech communities and to go against attempted hegemony. In 1884 the Dutch academic Mansvelt published an Afrikaans dictionary Proeve van een Kaapsch-Hollandsch Idioticon met Toelichtingen en Opmerkingen betreffende Land, Volk en Taal. He compiled this dictionary to prove that Afrikaans differs sufficiently from the then standard Dutch to be regarded as an emerging language and not merely a dialect of Dutch that has to conform to the rules of standard Dutch. As in the case of Changuion's word list, Mansvelt's dictionary was published at a time when English was the only official language in the Cape Province. The monolingual language policy and the consequent linguistic hegemony did not deter the continuing presence of an ever-changing emerging language or the attempts to impose an older form of linguistic hegemony amongst a certain group of speakers at the Cape.

The history of Afrikaans lexicography indicates that lexicographical attempts against linguistic hegemony were complemented by attempts to substitute linguistic hegemony with linguistic harmony. Notwithstanding an official language policy that only made provision for one official language, lexicographers attempted to ensure harmony between speakers of different languages. In 1902/1904 the Patriot Woordeboek/Patriot Dictionary was published. This dictionary, appearing shortly after the Anglo-Boer War (1899-1902), played a major role to introduce Afrikaans as an independent language coexisting alongside English. From the perspective of the development of Afrikaans lexicography, the Patriot Woordeboek/Patriot Dictionary played an extremely important role, which will not be discussed in this article. Of significance here is its attempt to ensure linguistic harmony in spite of the official language policy of linguistic hegemony. In the preface the editor of the Patriot Woordeboek/Patriot Dictionary concludes, after stating various aims and objectives: "This is our principal aim: to promote co-operation between the leading races, English and Dutch, in South Africa, for which purpose it is indispensable that they should mutually know each other's language ..." This dictionary does not adhere to an approach to expand English to the detriment of Afrikaans but it endeavours to create a form of harmony between speakers of English and Afrikaans.

In the first decades following its formal recognition as second official language besides English, much was done to promote Afrikaans. The beginning of the work on the Woordeboek van die Afrikaanse Taal (the WAT) in 1926 intro- 
duced a lexicographical era characterised by state support for this Afrikaans project. This support was increased substantially and the dictionary became one of the symbols of the success of Afrikaans. At a much later stage a much more limited financial allocation was made to the Dictionary of South African English. This support for the two official languages stood in sharp contrast to the lack of support for lexicographical projects in the other South African languages. Since the political transformation of 1994, there has been an official change in the favouring of only two languages to the detriment of the rest. The establishment of eleven national lexicography units, one for each of the official South African languages, has created the opportunity, at least in theory, for all the official languages to be promoted and to embark on lexicographical projects. In practice, however, the application of the official policy of eleven national languages leaves much to desire and it still has to be seen how this language policy will influence South African lexicography. The strong position of English as language of documentation has already resulted in the choice by a number of national lexicography units to compile bilingual dictionaries with English as partner language. If not managed in a proper way, this may lead to a new linguistic and lexicographical hegemony.

\subsection{Style selecting language policy}

This kind of language policy is part of some national language policies (cf. the discussion above and the citation from the Swedish Governmental proposal 2005). We are not aware of any such concrete national language policy plans in practice but in private companies and organisations below governmental level it is the most frequently used type of language policy plan. Their concern is better communicative habits to ensure a homogeneous language use (because a non-homogeneous language use sends a signal of non-professionalism) and a clear and easily understood communication. We only know of small corporate dictionaries (word lists) as part of corporate language policies, demanding e.g. the use of short words instead of long word formations or the abolishment of foreign words. Such demands are collected in small word lists, e.g. that of the Danish Pump Company (cf. Grundfos 2002 and Bergenholtz et al. 2003). For future corporate, but also national dictionaries we will suggest the development of an integrated outer text with style selecting proposals to which references from all relevant entries should be made.

\subsection{Linguistic units selecting language policy}

Dictionaries are too often regarded by their users as authoritative sources of knowledge that should never be questioned. However, as Samuel Johnson indicated, the authority of a dictionary is only that of its compiler. Yet, dictionaries are seen as sources in which the "proper" language usage is described and 
if a given form has been included in a dictionary the average dictionary user regards it as an indication that it had been accepted as part of the standard language. Once again it is important to be reminded of the remark by the editor of Webster's Third New International Dictionary of the English Language, Philip Gove, that the task of the dictionary is to record language, not to set its style. This would imply that a dictionary reflecting the real language should not be impeded by puristic considerations resulting from a biased or prescriptive approach on the side of the lexicographer.

An intralingual language policy may be an attempt to ensure the use of the standardised spelling system, and dictionaries may be required to utilise this standardised orthography. In this regard dictionaries often adhere to the orthography rules laid down by a formal language or spelling commission (cf. par. 4.5). For Afrikaans the Taalkommissie van die Suid-Afrikaanse Akademie vir Wetenskap en Kuns is the body responsible for the official ruling of Afrikaans orthography. Its decisions are published in the successive editions of the Afrikaanse Woordelys en Spelreëls and dictionaries are expected to abide by the spelling forms and rules presented in this book. A language policy may determine that orthography needs to be prescribed by a given body, and for dictionaries to fulfil their obligation as authoritative instruments it is wise to adhere to the laid-down criteria. Where evidence from actual language use goes against the suggestions and rules of the ruling body, dictionaries, depending on their type and function, could and should indicate the occurrence of the other forms as variants of the officially preferred form.

Only if one has the broad understanding of language policy we have chosen, decisions about orthography and inflection will be a part of a language policy. But this understanding accords exactly to the practice of a language policy for languages with a language commission taking official decisions of this kind, as can be illustrated from a few Danish examples. By law the decisions of the Danish Language Council are to be followed by all governmental employees and pupils or students in institutions of which more than $50 \%$ of their expenses are paid by the government. All decisions made by this council are published in an official dictionary. Until November 2001 - when a new edition of this dictionary appeared - there have been two officially valid variants for English line: Danish linie (with -ie) or linje (with -je). But since November 2001 only one variant (linje) has been permitted. Another example is the translation for the English combined power and heating plant station: Danish kraftvarmeværk, whose spelling without hyphens was the only valid form until November 2001. This is now forbidden and only kraft-varme-værk (with two hyphens) permitted. In the Danish language law from September 1997 (Law on Orthography 1997 and Law on Language Council 1997) and in the circular to this law (Circular on Danish Language Council 1997) we find two principles the Danish Language Council should use in its decisions on Danish orthography regulations. The first principle is a rule on consistency, called "the principle 
of tradition". It is a practical language-stabilizing rule, without which the changes would be so tremendous that it would be difficult to read texts written 30 or 50 years ago. The second principle is a rule of descriptivity called "the principle of language use". According to this rule the language council has to prescribe spelling according to the language use in texts written by good writers. $^{*}$ With such a law and with about 2000-3 000 spelling and inflexional changes within a few years, e.g. 1986, 1995, 2001 and 2006, there is a big need for updated dictionaries. Longer periods without changes and a proscriptive method - instead of the prescriptive one used - could be a good solution. In Denmark - and equally in other Scandinavian countries — we have an example of a language policy where a certain dictionary is explicitly mentioned as part of the law in its very first paragraph:

§ 1. Dansk retskrivning fastlægges af Dansk Sprognævn og offentliggøres i Dansk Sprognævns retskrivningsordbog. (Law on Orthography 1997)

[Danish orthography is decided by the Danish Language Council and is published in the spelling dictionary Retskrivningsordbogen]

The argument for the choice of one variant and the prohibition of another in cases like linie (forbidden since 2001) and linje (the only form allowed since 2001) is perhaps that the latter corresponds to the pronunciation, the former does not. Such an argument accords with the intention in the process of uniformity in many languages without a long tradition of being used as written language (cf. Chebanne et al. 2003: 3). Such cannot be the case in the Danish decision because this intention is not part of the language law (cf. the above reference to the principle of tradition as a main rule for official regulations: language use in texts written by good writers). Other changes can be explained as attempts to make the language more easily readable (prescribing the use of hyphens in long word formations like kraft-varme-værk. Such proposed changes have indeed a better chance of acceptance, if they accord with other orthographical conventions in a certain language. But the condition for a successful proposal is not only the acceptance of but also the easy access to information about the (new) norm. Dictionaries are the normal tools for quick access to such information. In that regard internet dictionaries are much more effective because the changes can immediately be communicated.

\subsection{Puristic language policy}

Language policy, as a form of intralingual language policy, is based on a particular historical, moral or political conception of proper language. Such a policy resorts primarily but not exclusively on an intralingual level and it should never be interpreted as being predominantly interlingual in nature. 
A puristic language policy often is an attempt to keep a language "pure" from either the influence of another language but, especially, from the influence of non-standard varieties, ideologically marked forms or derogatory words and expressions. This is the type of language policy that can lead to dicionaries eschewing the actual language use of their speech communities. A publisher may adhere to such a language policy and use its dictionaries to promote this approach. The individual lexicographer may adopt such a puristic approach in his/her dictionary, knowing quite well that the intended target user of the dictionary may very well interpret this approach as an official ruling on language.

During the first decades following the recognition of Afrikaans as an official language in South Africa there was a strong puristic approach to protect and free Afrikaans from Anglicisms. At that stage Afrikaans was attempting to maintain itself as official language alongside the world language English. Afrikaans linguists preferred forms originating from Dutch to loan-words from English. In the education system a strict puristic approach was implemented and learners often had to learn lists of Anglicisms along with their "pure" Afrikaans equivalents, in order to know which words and expressions to avoid.

The puristic urge in Afrikaans lexicography led to the inclusion of words that did not occur in typical day-to-day communication whilst forms with a high usage frequency, but stigmatised as Anglicisms, were omitted from dictionaries. In the fourteenth edition (1997) of Groot Woordeboek/Major Dictionary forms like bruismelk/roomysmelk/skuimmelk instead of melkskommel (for the English milkshake) and posbesteller/briewebesteller instead of posman/posbode (for the English postman) appeared. In the eighth edition (1984) of Tweetalige Woordeboek/Bilingual Dictionary a well-known Afrikaans word like geboortemerk (birthmark) is omitted in favour of the Dutch form moedervlek whilst bookmark gets the equivalents boeklêer and leeswyser but not the high-frequency word boekmerk (cf. Gouws 1993, 1995). This kind of puristic approach has impeded the lexicographical representation of actual Afrikaans usage.

True to its typological nature the comprehensive Woordeboek van die Afrikaanse Taal (WAT) has endeavoured to include a variety of Afrikaans forms without the same puristic approach. However, it is only in recent volumes of the WAT that informal English loan-words in Afrikaans are systematically lemmatised. In this regard many members of the Afrikaans speech community are still conservative, favouring the puristic approach in dictionaries. In the fourth edition (2000) of HAT, the Verklarende Handwoordeboek van die Afrikaanse Taal, a number of informal loan-words from English like cool, sorry, oukei, orraait were included and labelled to indicate their status. The inclusion of these words was the aspect of this dictionary which received the most criticism, several users insisting that the dictionary should adhere to an approach of including only pure Afrikaans words.

The inclusion of this type of loan-word was increased in the fifth edition (2005) of HAT due to a language policy on the side of the editors that aims to give a balanced account of the lexicon of Afrikaans, also allowing items coming 
even from non-standardised varieties. In contrast to this approach the implementation of a puristic language policy would have resulted in a much less representative account of the Afrikaans lexicon.

Dictionaries can play an important role to maintain the established "pure" forms but still acknowledge the occurrence of loan-words and -expressions, although these loan-forms may contradict the wishes of certain sections of the speech community. Whether they are pure or impure, the lexicographer needs to include these words, for which the knowledgeable user will be looking in the dictionary. In some of the African languages traditional words and loan-words coexist. Nong et al. (2002: 3) indicate that for Sepedi the former Language Board "adopted a sensible approach in being prescriptive in the coinage and approval/disapproval of terminology on the one hand, while still placing a high premium on actual usage as criterion for acceptability on the other hand", allowing for more than one option. For the months of the year the Language Board prescribed the use of "Sothoised" terms like Aprele (April) instead of Moranang (Nong et al. 2002: 4). Investigating the preference of users when it comes to traditional words versus loan-words, Nong et al. found that Sepedi speakers prefer traditional words like seyalemoya (radio) and setimela (train) to loan-words like radio and terene. The research indicated that $29,4 \%$ of the respondents prefer the loan-word only, while 70,6\% prefer the indigenous word only. However, the research also indicated that younger speakers have a stronger preference for loan-words than older speakers. Whereas the Language Board acknowledged certain loan-forms the existing Sepedi dictionaries display an even more lenient and less puristic approach towards loan-words. From the nine dictionaries investigated by Nong et al. it becomes clear that loan-words and their indigenous counterparts receive an equal treatment, with $50,6 \%$ of the loan-words and $49,4 \%$ of the indigenous counterparts included in the dictionaries.

Where the speech community clearly has a bias towards a more puristic approach, dictionaries are progressive and guide users by presenting them with different options. As indicated in the survey, the dictionary-internal language policy may go against the preferences of the majority of the speech community. Dictionaries reflect the usage patterns of the younger generation and still make provision for the preferences of the older generation.

The role of dictionaries in the purist drive is not only to approve or condemn loan-words as counterparts to indigenous forms. Dictionaries should also reflect on derogatory forms, for instance. In this regard the function of the dictionary and the target users will determine the possible inclusion of these forms and their treatment. It would be unacceptable for a comprehensive dictionary to omit sensitive words like Boer, rock-spider, kaffer and queer. Such an omission would imply a puristic approach to the detriment of the dictionary being representative of the lexicon of the language. The derogatory nature of these words should be indicated by means of labels, comments or even in the 
lexicographical definitions. Even in a school dictionary these words should be included but with an explicit warning against their use.

When it comes to a puristic language policy one cannot formulate a single approach for all dictionaries. As with the contents and structures of dictionaries the users and the lexicographical functions of each dictionary should determine the nature and extent of its puristic approach.

\section{Outlook for future dictionaries}

This article has indicated that further discussions of language policy issues should be preceded by a clear definition and understanding of terms from this field. As has been shown, these terms had not been efficiently treated in existing dictionaries and this applies both to dictionaries dealing with language for general purposes and those dealing with languages for special purposes. The current treatment is not really helpful but tends to be rather confusing.

In this article, we defined the terms in such a way that they can be employed in an LSP (language for special purposes) dictionary that focuses on language planning. The discussion included suggestions for terminological use by politicians, journalists and other language users participating in the discussion.

The main thesis of the article is that lexicographers of concrete dictionaries constantly make decisions relevant to language policy. This does not only regard the domain that clearly belongs to party or national politics but also the domain of general decisions regarding language and languages. This implies a wide scope of the lexical item policy as can be seen in its occurrence in a combination like smoking policy.

Language policy has three basic dimensions: the choice of communication channels, the choice between languages and the choice between an interlingual and an intralingual approach. These dimensions also apply to lexicography and we want to emphasise that interlingual and intralingual decisions should be directed at each other and that both these dimensions are indispensable. Up to now intralingual decisions have been the obvious ones for lexicographers. This article acknowledges this, but also stresses the additional necessity and relevance of decisions on the level of communication policy and interlingual language policy.

\section{Endnote}

* In practice the Danish Language Council does not follow these clear rules (Bergenholtz 2003a, 2003b); the concrete decisions are therefore criticized in public discussion. But the debate is not as serious as a similar discussion in Germany (after their language decisions in 1996). A reason for this could be, that new general changes in Germany only take place once in a hundred years, whereas in Denmark changes occurred more than ten times in the same period. 


\section{Literature}

About South Africa. 2005. Pan South African Language Board. <http://www.southafrica.info/ess_ info/sa_glance/constitution/pansalb.htm $>$ [January 2006].

Alexander, N. 1996. Introduction. Lexicography as a Financial Asset 1996: 3-6.

Bathily, A. 2005. Strategic Thinking. Community Radio in Senegal Today. Issues and Outlooks. $<\mathrm{http} / / /$ www.comminit.com/africa/strategicthinking/st2005/thinking-1053.html> [November 2005].

Bergenholtz, H. 1996. Norsk international ordbog [review of Norsk ordbok. Ordbok over det norske folkemålet og det nynorske skriftmålet. Band III. Flusker-Gigla. Edited by Reidar Bø, Arnbjørg Hageberg, Laurits Killingbertrø, Sigurd Norlie and Gunnar Pedersen. Oslo: Det Norske Samlaget 1994.]. Norsk Lingvistisk Tidsskrift 14: 75-84.

Bergenholtz, H. 1997. Polyfunktionale ordbøger. LexicoNordica 4: 15-29.

Bergenholtz, H. 2003a. User-oriented Understanding of Descriptive, Proscriptive and Prescriptive Lexicography. Lexikos 13: 65-80.

Bergenholtz, H. 2003b. Bryder Dansk Sprognævn den danske sproglov? Sprogpolitik i teori og praksis. Lönnroth, Harry (Ed.). Från Närpesdialekt till EU-svenska. Festskrift till Kristina Nikula: 17-31. Tammerfors: Tampere University Press.

Bergenholtz, H. 2006. Toward a Definition of Communication Policy, Language Policy and Language Planning. SPIL PLUS: Stellenbosch Papers in Linguistics Plus 34.

Bergenholtz, H. and S.-G. Malmgren. 1998. Förord. LexicoNordica 7: 1-4.

Bergenholtz, H. and S. Tarp. 2003. Two Opposing Theories: On H.E. Wiegand's Recent Discovery of Lexicographic Functions. Hermes, Journal of Linguistics 31: 171-196.

Bergenholtz, H. and S. Tarp (Eds.). 1995. Manual of Specialised Lexicography. The Preparation of Specialised Dictionaries. Amsterdam: Benjamins.

Bergenholtz, H., J. Bisgaard, M.B. Lauridsen and K.K. Wichmann. 2003. Sprogpolitik: So ein Ding müssen wir auch haben. Hermes, Journal of Linguistics 31: 135-165.

Brockhaus-Wahrig = Wahrig, G., H. Krämer and H. Zimmermann (Eds.). 1980-1984. Brockhaus-Wahrig. Deutsches Wörterbuch in sechs Bänden. Wiesbaden: Brockhaus/Stuttgart: Deutsche Verlagsanstalt.

Bünting and Karatas = Bünting, Karl-Dieter and Ramona Karatas. 1996. Deutsches Wörterbuch. Mit der neuen Rechtschreibung. Chur: Isis.

Cameron, D. 1995. Verbal Hygiene. London/New York: Routledge.

Changuion, A.N.E. $1848^{2}$. Proeve van Kaapsch taaleigen. Changuion, A.N.E. $1848^{2}$. De Nederduitsche taal in Zuid-Afrika hersteld, zijnde eene handleiding tot de kennis dier taal, naar de plaatselijke behoefte van het land gewijzigd: i-xxvi. Rotterdam: J. van der Vliet.

Chebanne, Andy, Mbulelo Jokweni, Makali Isabella Mokitimi and Sihawukele Ngubane. 2003. Introduction. The Symposium and the Book. Unifying Southern African Languages. Harmonization and Standardization: 1-11. Cape Town: The Centre for Advanced Studies of African Society (CASAS).

Circular on Danish Language Council $=$ Bekendtgørelse om Dansk Sprognævns virksomhed og sammensætning. Bekendtgørelse nr. 707 af 4.9.1997. Lovtidende, A. 1997: 3745-3746. <http:// www. dsn.dk/> [February 2006].

Danish Culture Ministry. 2003. Sprog på spil. Et udkast til en dansk sprogpolitik. Copenhagen: Kulturministeriet. <http://www.kum.dk/graphics/kum/downloads/Publikationer/Sprog_paa_ spil.pdf $>$ [February 2006]. 
Den Danske Netordbog = Bergenholtz, Henning and Vibeke Vrang with contributions by Lena Lund, Helle Grønborg, Maria Bruun Jensen, Signe Rixen Larsen, Rikke Refslund and Jette Pedersen. 2004. Den Danske Netordbog. Database and layout: Richard Almind. <http://netordbog.asb. $\mathrm{dk}>$.

Dictionary of South African English = Silva, Penny (Mng. Ed.). 1996. A Dictionary of South African English on Historical Principles. Oxford: Oxford University Press.

Duden-GWD $=$ Duden. Das große Wörterbuch der deutschen Sprache in sechs Bänden. 1976-1981. Edited and compiled by the Wissenschaftlicher Rat and the collaborators of the Dudenredaktion under the direction of Günther Drosdowski. Mannheim/Vienna/Zurich: Bibliographisches Institut.

Duden-GWD2 = Duden. Das große Wörterbuch der deutschen Sprache in acht Bänden. 1993-1995. Second, completely newly edited and strongly enlarged edition. Edited and compiled by the Wissenschaftlicher Rat of the Dudenredaktion under the direction of Günther Drosdowski. Mannheim/Vienna/Zurich: Bibliographisches Institut.

Duden-GWD $=$ Duden. Das große Wörterbuch der deutschen Sprache in zehn Bänden. 1999. Third, completely newly edited and enlarged edition. Edited by the Wissenschaftlicher Rat of the Dudenredaktion. Mannheim/Leipzig/Vienna/Zurich: Dudenverlag.

Duden-Universalwörterbuch $=$ Duden. Deutsches Universalwörterbuch. 2003. Edited by the Dudenredaktion. Fifth revised edition. Mannheim/Leipzig/Vienna/Zurich: Dudenverlag.

Fettes, M. 1997. Language Planning and Education. Wodak, Ruth and David Corson (Eds.). 1997. Encyclopedia of Language and Education. Volume 1. Language Policy and Political Issues in Education: 13-22. Dordrecht/Boston/London: Kluwer.

Gallardo, A. 1980. Dictionaries and the Standardization Process. Zgusta, L. (Ed.). 1980. Theory and Method in Lexicography: 59-69. Columbia: Hornbeam Press.

Gouws, R.H. 1989. Leksikografie. Pretoria/Cape Town: Academica.

Gouws, R.H. 1993. Normatiewe leiding in woordeboeke: 'n nuwe benadering. Lexikos 3: 49-66.

Gouws, R.H. 1995. Dictionaries and the Dynamics of Language Change. Kachru, B. (Ed.). 1995. Culture, Ideologies and the Dictionary: 297-313. Tübingen: Max Niemeyer Verlag.

Gouws, R.H. 1996. A Sequence for Meeting Lexicographic Needs. Lexicography as a Financial Asset. 1996: 97-110.

Gouws, R.H. 2005. Lexicography in Africa. Brown, K. (Ed.). 2005. Encyclopedia of Language and Linguistics: 95-101. Second edition. Oxford: Elsevier.

Gouws, R.H. and F.A. Ponelis. 1992. The Development of Afrikaans and the Lexicographic Tradition. Zgusta, L. (Ed.). 1992. History, Languages and Lexicographers: 77-104. Tübingen: Max Niemeyer Verlag.

Gouws, R.H. and D.J. Prinsloo. 2005. Principles and Practice of South African Lexicography. Stellenbosch: SUN PReSS.

Gove, P.B. 1961. Webster's Third New International Dictionary of the English Language. Springfield, Mass.: Merriam Webster.

Groot Woordeboek/Major Dictionary = Eksteen, L.C. (Ed.). 199714. Groot Woordeboek Afrikaans-Engels/ Engels-Afrikaans / Major Dictionary Afrikaans-English/English-Afrikaans. Cape Town: Pharos.

Grundfos $=$ Med andre ord ... Grundfos' sprogpolitik. 2002. Bjerringbro: Grundfos.

Hartmann, R.R.K. and G. James. 1998. Dictionary of Lexicography. London/New York: Routledge.

Haugen, E. 1959. Planning for a Standard Language in Modern Norway. Anthropological Linguistics 1(3): 8-21. 
Hausmann, F.J. 1977. Einführung in die Benutzung der neufranzösischen Wörterbücher. Tübingen: Max Niemeyer Verlag.

International Encyclopedia of Lexicography = Hausmann, F.J., O. Reichmann, H.E. Wiegand and L. Zgusta (Eds.). 1989-1991. Wörterbücher. Ein internationales Handbuch zur Lexikographie/Dictionaries. An International Encyclopedia of Lexicography/Dictionnaires. Encyclopédie internationale de lexicographie. Berlin/New York: Walter de Gruyter.

Kamwangamalu, N.M. 2004. The Language Planning Situation in South Africa. Baldauf, Richard B. Jr and Robert B. Kaplan (Eds.). 2004. Language Planning and Policy in Africa, Vol. 1. Botswana, Malawi, Mozambique and South Africa: 197-281. Clevedon/Buffalo/Toronto: Multilingual Matters.

Kidda Awak, M. 1990. Historical Background, with Special Reference to Western Africa. Hartmann, R.R.K. (Ed.). 1990. Lexicography in Africa: 8-18. Exeter: Exeter University Press.

Kotler, P. and K.L. Keller. 2006. Marketing Management. Twelfth edition. Upper Saddle River, N.J.: Prentice Hall.

Lakoff, R. 1990. Talking Power: The Politics of Language in our Lives. New York: Basic Books.

Landau, S.I. 1981. Dictionaries: The Art and Craft of Lexicography. New York: Schribner Press.

Langgård, P. 1997. Ordbogersuaq, den store grønlandske ordbog, der ikke blev til noget — nogle etnopolitiske overvejelser. LexicoNordica 4: 83-100.

Language Policy and Plan for South Africa = Final Draft: Language Policy and Plan for South Africa. 2000. By the Advisory Panel on Language Policy. To the Minister of Arts, Culture, Science and Technology, 6 November 2000. <http://www.dac.gov.za/about_us/cd_nat_language/language_policy/Language \%20Policy\%20and\%20Plan\%20for\%20South\%20Africa.htm> [January 2006].

Law on Language Council = Sprognævnsloven Lov nr. 320 af 14.5.1997 om Dansk Sprognævn. Lovtidende, A. 1997: 1497-1498. <http://www.dsn.dk/> [February 2006].

Law on Orthography = Retskrivningsloven Lov nr. 332 af 14.5.1997 om Dansk Retskrivning. Lovtidende, A. 1997: 1521. <http://www.dsn.dk/> [February 2006].

Lexicography as a Financial Asset = Lexicography as a Financial Asset in a Multilingual South Africa. Seminar held at the Bureau of the WAT, University of Stellenbosch, 12 April 1996. 1996. Language Planning Report No. 5.3. October 1996. Pretoria: Department of Arts, Culture, Science and Technology.

Lopes, A.J. 2004. The Language Planning Situation in Mozambique. Language Planning and Policy in Africa, Vol. 1. Botswana, Malawi, Mozambique and South Africa. Baldauf, Richard B., Jr and Robert B. Kaplan (Eds.). 2004: 150-196. Clevedon/Buffalo/Toronto: Multilingual Matters.

Malagasy-Aleman Dictionary = Bergenholtz, H. in co-operation with S. Rajaonarivo, R. Ramasomanana, B. Radanielina as well as J. Richter-Johanningmeier, E. Olszowski, V. Zeiss in collaboration with H. Ranaivoson, N. Rasoarimanana, R. Ravololomboahangy and M. Razafiarivony. 1991. Rakibolana Malagasy-Alema/Madagassisch-Deutsches Wörterbuch. Antananarivo: Leximal/Moers: Aragon.

Mansvelt, N. 1884. Proeve van een Kaapsch-Hollandsch idioticon met toelichtingen en opmerkingen betreffende land, volk en taal. Cape Town: Van de Sandt de Villiers en Co.

Mavoungou, P.A. 2002. Metalexicographical Criteria for the Compilation of a Trilingual Dictionary: Yilumbu-English-French. Unpublished Doctoral Dissertation. Stellenbosch: University of Stellenbosch.

Mini, B.M. 1996. The Lexicographic Needs of Xhosa. Lexicography as a Financial Asset: 67-74. 
Nong, S., G.-M. de Schryver and D.J. Prinsloo. 2002. Loan Words versus Indigenous Words in Northern Sotho - A Lexicographic Perspective. Lexikos 12: 1-20.

Nordic Dictionary of Lexicography = Bergenholtz, H., I. Cantell, R.V. Fjeld, D. Gundersen, J.H. Jónsson and B. Svensén. 1997. NLO. Nordisk leksikografisk ordbog. Oslo: Universitetsforlaget.

Norwegian Language Council $=$ Rettskrivningsendringer fra 1. juli 2005. 2005. Oslo. <http://www. sprakrad.no/upload/9630/rettskriving2005.doc> [February 2006].

Nyangone Assam, B. and P.A. Mavoungou. 2000. Lexicography in Gabon: A Survey. Lexikos 10: 252-274.

Patriot Woordeboek/Patriot Dictionary = Anonymous (S.J. du Toit). 1902/1904. Patriot Woordeboek Afrikaans-Engels / Patriot Dictionary Cape Dutch-English. Paarl: D.F. du Toit.

Prinsloo, D.J. 1996a. The Lexicographic Needs of Pedi. Lexicography as a Financial Asset: 37-45.

Prinsloo, D.J. 1996b. The Lexicographic Needs of Sotho. Lexicography as a Financial Asset: 47-52.

Richards, J., J. Platt and H. Platt. 1992. Dictionary of Language Teaching and Applied Linguistics. London: Longman.

Spolsky, Bernard. 2004. Language Policy. Cambridge: Cambridge University Press.

Strauß, G., U. Haß and G. Harras. 1989. Brisante Wörter von Agitation bis Zeitgeist. Ein Lexikon zum öffentlichen Sprachgebrauch. Berlin/New York: De Gruyter.

Svensén, B. 1993. Practical Lexicography. Principles and Methods of Dictionary-Making. Translated from the Swedish by John Sykes and Kerstin Schofield. Oxford/New York: Oxford University Press.

Swedish Governmental Proposal = Bästa språket - en samlad svensk språkpolitik. 2005. Stockholm. <http://www.regeringen.se/sb/d/5969/a/50740> [February 2006].

Tanzania = National Information and Communication Infrastructure (NICI) Policies and Plans (e-strategies). 1997. <http://www.uneca.org/aisi/nici/Tanzania/tanzania.htm> [November 2005].

Tauli, V. 1974. The Theory of Language Planning. Fishman, Joshua A. (Ed.). 1974. Advances in Language Planning: 49-67. The Hague: Mouton.

The Language Plan Task Group (LANGTAG). 1996. Toward a National Language Plan for South Africa: Final Report of the Language Plan Task Group. Pretoria: DACST.

Trask, R.L. 1997. A Student's Dictionary of Language and Linguistics. London/New York/Sydney/ Auckland: Arnold.

Tweetalige Woordeboek/Bilingual Dictionary = Bosman, D.B. et al. (Eds.). 19848. Tweetalige Woordeboek/Bilingual Dictionary. Cape Town: Tafelberg.

Van Dale Groot Woordenboek Nederlands-Engels = Martin, W. (Ed.). 1999. Van Dale Groot Woordenboek Nederlands-Engels. Utrecht: Van Dale Lexicografie.

Van Dale Groot Woordenboek der Nederlandse Taal = Geerts, G. and T. den Boon in co-operation with D. Geeraerts and E. Vos. Etymology by N. v.d. Sijs. 1999. Van Dale Groot Woordenboek der Nederlandse Taal. Thirteenth revised edition S-Z. Utrecht/Antwerp: Van Dale Lexicographie.

Van der Merwe, H.J.J.M. 1971. Vroeë Afrikaanse Woordelyste. Pretoria: J.L. van Schaik.

Verklarende Afrikaanse Woordeboek = Labuschagne, F.J. and L.C. Eksteen. 19938. Verklarende Afrikaanse Woordeboek. Eighth revised and augmented edition. Pretoria: Van Schaik.

Verklarende Handwoordeboek van die Afrikaanse Taal = Odendal, F.F. and R.H. Gouws. 20004/20055 Verklarende Handwoordeboek van die Afrikaanse Taal. Cape Town: Pearson Education.

Wahrig = Wahrig, Gerhard. 2000. Deutsches Wörterbuch . Newly edited by Renate Wahrig-Burfeind. With a "Lexikon der deutschen Sprachlehre". Gütersloh/Munich: Bertelsmann. 
Webb, V. 2002. Language in South Africa: The Role of Language in National Transformation, Reconstruction and Development. Amsterdam/Philadelphia: Benjamins.

Wiegand, H.E. 1998. Wörterbuchforschung. Untersuchungen zur Wörterbuchbenutzung, zur Theorie, Geschichte, Kritik und Automatisierung der Lexikographie. 1. Teilband. Berlin/New York: De Gruyter.

Woordeboek van die Afrikaanse Taal. Stellenbosch: Buro van die Woordeboek van die Afrikaanse Taal. $<$ http: //www.yourdictionary.com>.

Zeitgeschichtliches Wörterbuch = Stötzel, G. and T. Eitz in collaboration with A. Jährling-Marienfeld, L. Plate a.o. 2003. Zeitgeschichtliches Wörterbuch der deutschen Gegenwartssprache. Second enlarged and updated edition. Hildesheim/Zurich/New York: Georg Olms Verlag.

Zgusta, L. 1971. Manual of Lexicography. Prague: Academia / The Hague/Paris: Mouton. 